\title{
Computational model of a modulatory cell type in the feeding network of the snail, Lymnaea stagnalis
}

\section{Dimitris V Vavoulis*1,2, Eugeny S Nikitin², Jianfeng Feng1, Paul R Benjamin ${ }^{2}$ and György Kemenes ${ }^{2}$}

Address: ${ }^{1}$ Ctr. for Scientific Computing, University of Warwick, Coventry, UK and ${ }^{2}$ Sussex Ctr. for Neuroscience, University of Sussex, Brighton, UK

Email: Dimitris V Vavoulis* - Dimitris.Vavoulis@dcs.warwick.ac.uk

* Corresponding author

from Sixteenth Annual Computational Neuroscience Meeting: CNS*2007

Toronto, Canada. 7-12 July 2007

Published: 6 July 2007

BMC Neuroscience 2007, 8(Suppl 2):PI I3 doi:I0.I I86/I47I-2202-8-S2-PI I3

(C) 2007 Vavoulis et al; licensee BioMed Central Ltd.

\section{Introduction}

Realistic mathematical models of single neurons are significant in assessing the contribution of specific ionic conductances to neuronal excitability. This study presents a detailed computational model of the Cerebral Giant Cells (CGCs), a pair of serotonergic neurons in the feeding network of Lymnaea stagnalis, which are critical for the expres- sion of motor behaviour (feeding) and the formation of long-term memory.

\section{Methods}

First, we fitted a single-compartment, Hodgkin-Huxley model of the CGCs to two-electrode voltage- and currentclamp data [1] using a combination of linear and non-lin-
A) Overview of the CGC model

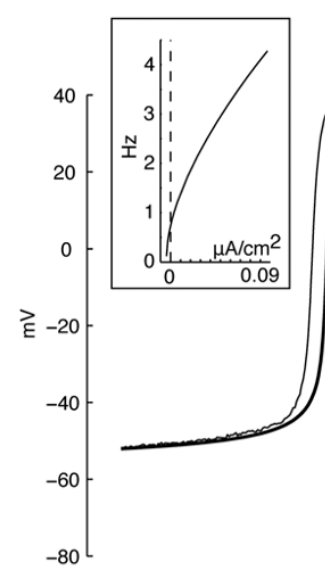

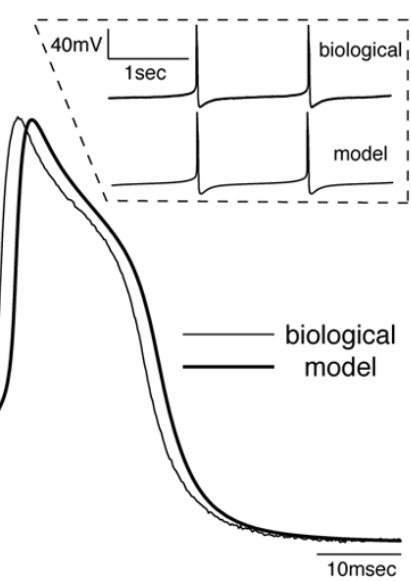

B) Selective block of ionic currents
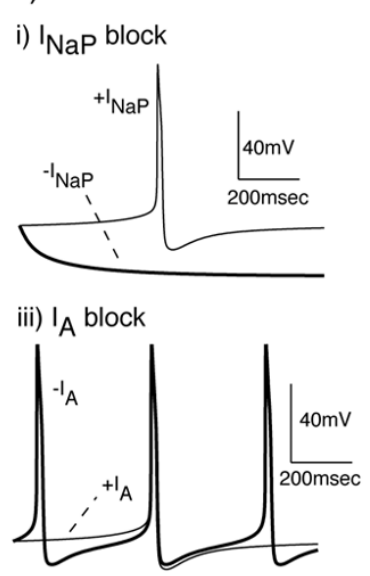

ii) ILVA block

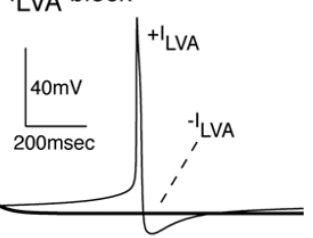

iv) IHVA block

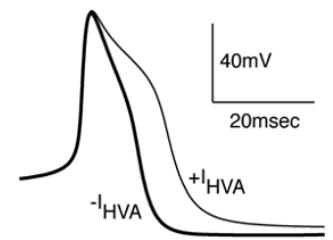

Figure I

Overview of the CGCs model and the contribution of specific currents to neuronal excitability. In A, the model has been shifted to the right by $2 \mathrm{msec}$ compared to the biological action potential. 
ear least-square fitting techniques. Then, we selectively blocked each ionic current to assess its role in the model, thus mimicking the application of pharmacological agents in the biological neuron.

\section{Results}

The model replicates accurately the shape of the action potentials and the tonic firing $(\sim 0.74 \mathrm{~Hz})$ of the biological neuron (Fig. 1A). A persistent sodium current $I_{N a P}$ and a transient low-threshold calcium current $I_{L V A}$ keep the neuron spontaneously active (Fig. 1Bi, ii). A transient potassium current $I_{A}$ regulates the interspike interval, while a transient high-threshold calcium current $I_{H V A}$ increases the duration of each spike (Fig. 1Biii, iv). Transient sodium and delayed rectifier potassium currents are responsible for the depolarizing and repolarizing phases of the action potential, as in the classical Hodgkin-Huxley model. The available experimental data [1] are in agreement with these conclusions.

\section{Conclusion}

The model we have developed here provides an accurate description of the CGCs at the biophysical level and it is a useful tool for studying the electrical properties of these important modulatory neurons.

\section{Acknowledgements}

This research was supported by EPSRC and BBSRC, United Kingdom

\section{References}

I. Staras K, Gyori J, Kemenes G: Voltage-gated ionic currents in an identified modulatory cell type controlling molluscan feeding. Eur J Neurosci 2002, 15:109-119.
Publish with Bio Med Central and every scientist can read your work free of charge

"BioMed Central will be the most significant development for disseminating the results of biomedical research in our lifetime. " Sir Paul Nurse, Cancer Research UK

Your research papers will be:

- available free of charge to the entire biomedical community

- peer reviewed and published immediately upon acceptance

- cited in PubMed and archived on PubMed Central

- yours - you keep the copyright

Submit your manuscript here:

http://www.biomedcentral.com/info/publishing_adv.asp 